INTERNATIONAL JOURNAL OF RESEARCHES IN BIOSCIENCES, AGRICULTURE \& TECHNOLOGY ( ) VISHWASHANTI MULTIPURPOSE SOCIETY (Global Peace Multipurpose Society) R. No. MH-659/13(N) www.vmsindia.org

\title{
EFFECT OF WEATHER PARAMETER ON RABI MUSTARD VARIETIES UNDER DIFFERENT SOWING DATES
}

\author{
Jiotode D.J., Parlawar N.D., Patil S.R., Kuchanwar O.D., Khawle V.S. and \\ Dhanwate A.G.
}

College of Agriculture, Nagpur Dr. P.D.K.V. Akola (M.S) India Email: djiotode@rediffmail.com

\begin{abstract}
The present investigation was carried out at Agronomy Farm, College of Agriculture, Nagpur during rabi season of 2015-16. The experiment was laid out in split plot design consisting five main treatments of sowing dates viz., $\mathrm{D}_{1}\left(42^{\text {nd }} \mathrm{MW}\right), \mathrm{D}_{2}\left(43^{\text {rd }} \mathrm{MW}\right), \mathrm{D}_{3}\left(44^{\text {th }} \mathrm{MW}\right), \mathrm{D}_{4}\left(45^{\text {th }} \mathrm{MW}\right)$ and $\mathrm{D}_{5}\left(46^{\text {th }} \mathrm{MW}\right)$ and two sub-treatments of varieties viz., $\mathrm{V}_{1}$ (Pusa bold) and $\mathrm{V}_{2}(\mathrm{ACN}-9)$ replicated thrice. The final plant population at harvest was not significantly influenced due to sowing dates. Plant height, number of branches plant ${ }^{-1}$, dry matter accumulation plant ${ }^{-1}$, total number of siliquae plant ${ }^{-1}$ and number of siliquae plant $^{-1}$ was highest on $\mathrm{D}_{2}\left(43^{\mathrm{rd}} \mathrm{MW}\right)$. Highest seed yield ha-1 $(820 \mathrm{~kg})$ was recorded in the treatment $\mathrm{D}_{2}$ $\left(43^{\text {rd }} \mathrm{MW}\right)$. Gross monetary returns and net monetary returns and benefit cost ratio was highest in sowing on $\mathrm{D}_{2}\left(43^{\text {rd }} \mathrm{MW}\right)$. Plant height, number of branches plant $\mathrm{t}^{-1}$, and dry matter accumulation plant ${ }^{-1} \mathrm{were}^{-}$ significantly influenced on all growth stages. Variety $\mathrm{V}_{1}$ (Pusa bold) found significantly superior over $\mathrm{V}_{2}$ (ACN-9) for all the traits. The gross and net monetary returns and also benefit-cost ratio was more in $\mathrm{V}_{1}$ (Pusa bold) variety which was superior with $\mathrm{V}_{2}$ (ACN-9). Interaction effects of sowing dates and varieties were found to be non-significant in respect of growth, yield attributes, quality parameters and economics of mustard crop, except seed yield. Highest seed yield were recorded (853 $\mathrm{kg} \mathrm{ha}^{-1}$ ) between $\mathrm{D}_{2}\left(43^{\mathrm{rd}} \mathrm{MW}\right)$ and $\mathrm{V}_{1}$ (Pusa bold) combination. It is inferred from this study that sowing of mustard during $43^{\mathrm{rd}} \mathrm{MW}$ and the variety Pusa bold significantly improved all the growth, seed yield and yield components traits of mustard. Thermal requirement and thermal use efficiency of mustard was also more when crop was sown on $43^{\text {rd }} \mathrm{MW}\left(\mathrm{D}_{2}\right)$.
\end{abstract}

Keywords: Mustard, Sowing, Varieties, Weather parameter

\section{Introduction:}

Mustard is important oilseeds crop. Seed contain 33 to 40 per cent oil and is mainly utilized for human consumption throughout northern India for cooking as well as frying purpose. In India, area under mustard cultivation is 71.30 lakh hectares producing about 73 lakh tones of seeds with average productivity of $1023 \mathrm{~kg}$ hectares (Anonymous, 2014a). Area was under mustard cultivation in Maharashtra was 12000 hectares with production of 4000 tones and average productivity of $308 \mathrm{~kg}$ ha1 and $865 \mathrm{~kg} \mathrm{ha}^{-1}$ area was under cultivation in Vidarbha region having production of 330 tones and productivity of $380 \mathrm{~kg} \mathrm{ha-1}$ (Anonymous, 2014b).

At present the yield of mustard is low, there are many reasons for low productivity of mustard, viz; cultivation under stored soil moisture or limited irrigation water etc. out of various package of practices primary factors like optimum sowing dates and suitable varieties for the region are the most important and hence these factors were considered on priority basis under the present study. Another reason of yield reduction is non-availability of suitable variety for a particular agro-climate.

Since the rate of development of crop $\&$ oil in seed is greatly influenced by the variation in temperature, humidity $\&$ other biotic factors. Sowing either too early or too late has been reported to be harmful. Not only dates of sowing but varieties or cultivar grown also have major contribution in increasing the yield potential in mustard. Adoption of improved variety and suitable crop management practices are important factor for improving crop productivity. Sowing time plays important role in crop husbandry and remains to be the prominent factors in deciding seed as well as oil yield. Optimum sowing time is an important nonmonetary input and if managed properly, it helps to enhance seed yield. Sowing of mustard at inappropriate time reduce seed yield and yield attributes.

The study of efficient utilization of the weather parameters is necessary. With this contest the present study entitled "Effect of weather parameter on rabi mustard (Brassica juncea) varieties under different sowing dates" was carried out with the 
objectives (i) to find out the effect of weather parameter on growth \& yield of mustard and (ii) to study the thermal requirement \& thermal use efficiency of mustard variety.

\section{Materials and methods:}

The experiment was laid out in "split plot design" with five treatments of dates of sowing ( $\mathrm{D}_{1}-42^{\text {nd }} \mathrm{MW}, \mathrm{D}_{2}-43^{\text {rd }} \mathrm{MW}, \mathrm{D}_{3}-$ 44th MW. D4 $-45^{\text {th }}$ MW D5 $-46^{\text {th }}$ MW) under main plot treatments and two varieties ( $\mathrm{V}_{1}$ - Pusa bold, $\left.\mathrm{V}_{2}-\mathrm{ACN}-9\right)$ as sub plot treatment forming 10 treatment combination and replicated three times during rabi 2015 at Agronomy farm, College of Agriculture, Nagpur. The gross and net plot size were $3.6 \mathrm{~m} \times 4.8 \mathrm{~m}$ and $2.7 \mathrm{~m} \mathrm{x}$ $4.2 \mathrm{~m}$, respectively. A spacing of $45 \times 15 \mathrm{~cm}$ was adopted by using $5 \mathrm{~kg}$ seed ha-1. The pre harvest biometric observations on plant stand, were recorded at the time of harvest and plant height $(\mathrm{cm})$, number of branches plant -1 , dry matter accumulation plant ${ }^{-1}$ were recorded periodically at 30 days interval after sowing and at harvest from five representative plants. The post harvest biometric observations were recorded on total number of siliquae plant ${ }^{-1}$, seed yield plant $^{-1}(\mathrm{~g})$, seed yield $\left(\mathrm{kg} \mathrm{ha}^{-1}\right)$, biomass yield (kg ha-1), straw yield plant-1 (g) and straw yield (kg ha-1) after harvest from five representative plants. The benefit : cost ratio was worked out by the dividing the gross monetary returns (Rs.ha-1) with total cost of cultivation (Rs.ha-1). Temperature (Thermal) requirement, also referred as thermal unit, for each calendar day during crop period, for all the treatment were calculated from daily weather data on maximum and minimum temperature as under

$$
\text { Thermal requirement }=\frac{\mathrm{T}_{\text {Max }}+\mathrm{T}_{\text {Min }}}{2}
$$

Where, $\mathrm{T}_{\text {Max }}-\quad$ Maximum temperature , $\mathrm{T}_{\text {Min _ - } \quad \text { Minimum temperature }}$

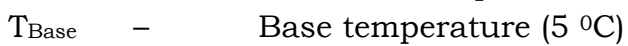

Base temperature is the temperature below which the physiological activities in plant practically cease and as a result plant does not show any growth. It is considered as 5 ${ }^{\circ} \mathrm{C}$ for mustard crop. Further total thermal unit requirement over crop period under each treatment was calculated by summation. In present study base temperature for mustard was taken as $5{ }^{\circ} \mathrm{C}$. Thermal use efficiency $\left(\mathrm{kg} / \mathrm{ha} / \mathrm{D}^{\circ} \mathrm{C}\right)$ on the basis of grain yield, straw yield, and biomass yield of mustard varieties.

The data collected during the course of investigation was statistically analyzed by adopting standard method known as "Analysis of variance" (Panse and Sukhatme, 1971). Wherever the results were found significant, critical difference (C.D.) were worked out at 5 per cent level of probability of comparison of treatment means. The treatment effects were presented by making table of means with appropriate standard error (S.E.) and C.D. value.

\section{Results and Discussion: Pre-harvest studies}

Data regarding pre-harvest traits as influenced by various treatments are presented in Table-1.

\begin{tabular}{|c|c|c|c|c|c|c|c|c|c|c|c|c|c|}
\hline \multirow[t]{2}{*}{ Treatments } & \multirow{2}{*}{$\begin{array}{l}\text { Final } \\
\text { plant } \\
\text { stand } \\
\text { plot }^{-1}\end{array}$} & \multicolumn{4}{|c|}{ Plant height $(\mathrm{cm})$} & \multicolumn{4}{|c|}{ Number of branches plant ${ }^{-1}$} & \multicolumn{4}{|c|}{ Dry matter accumulation plant ${ }^{-1}$} \\
\hline & & $30 \mathrm{DAS}$ & $60 \mathrm{DAS}$ & $90 \mathrm{DAS}$ & $\begin{array}{c}\text { At } \\
\text { harvest }\end{array}$ & $30 \mathrm{DAS}$ & $60 \mathrm{DAS}$ & 90 DAS & $\begin{array}{c}\text { At } \\
\text { harvest }\end{array}$ & $\begin{array}{c}30 \\
\text { DAS }\end{array}$ & $60 \mathrm{DAS}$ & $90 \mathrm{DAS}$ & $\begin{array}{c}\text { At } \\
\text { harvest }\end{array}$ \\
\hline \multicolumn{14}{|l|}{ Sowing Dates } \\
\hline $\mathrm{D}_{1}-42^{\text {nd }} \mathrm{MW}$ & 156 & 10.23 & 136.30 & 148.17 & 158.88 & 2.73 & 5.89 & 8.74 & 9.82 & 6.85 & 15.78 & 23.77 & 32.39 \\
\hline $\mathrm{D}_{2}-43^{\text {rd }} \mathrm{MW}$ & 159 & 10.50 & 141.93 & 154.48 & 163.51 & 2.99 & 6.02 & 9.79 & 10.16 & 7.53 & 16.33 & 24.43 & 33.48 \\
\hline $\mathrm{D}_{3}-44^{\text {th }} \mathrm{MW}$ & 157 & 9.35 & 133.08 & 142.12 & 156.51 & 2.53 & 5.78 & 8.44 & 9.56 & 6.55 & 15.50 & 22.76 & 32.13 \\
\hline $\mathrm{D}_{4}-45^{\text {th }} \mathrm{MW}$ & 155 & 9.08 & 131.98 & 140.93 & 151.87 & 2.32 & 5.61 & 8.08 & 9.46 & 6.22 & 14.41 & 19.68 & 30.32 \\
\hline $\mathrm{D}_{5}-46^{\text {th }} \mathrm{MW}$ & 154 & 8.75 & 129.40 & 138.30 & 148.08 & 2.12 & 5.45 & 7.73 & 9.0 & 5.83 & 13.77 & 18.42 & 28.38 \\
\hline $\mathrm{SE}(\mathrm{m}) \pm$ & 1.07 & 0.38 & 0.63 & 0.92 & 1.20 & 0.02 & 0.03 & 0.09 & 0.11 & 0.09 & 0.16 & 0.23 & 0.33 \\
\hline CD at $5 \%$ & N.S. & N.S. & 2.05 & 3.01 & 3.76 & N.S. & 0.12 & 0.30 & 0.33 & N.S. & 0.54 & 0.76 & 1.06 \\
\hline \multicolumn{14}{|l|}{ Varieties } \\
\hline$V_{1}-$ Pusa bold & 157 & 9.93 & 135.75 & 146.53 & 159.14 & 2.64 & 5.79 & 8.92 & 10.03 & 7.07 & 16.07 & 22.45 & 32.43 \\
\hline $\mathrm{V}_{2}-\mathrm{ACN}-9$ & 156 & 9.24 & 133.33 & 143.07 & 152.40 & 2.44 & 5.70 & 8.19 & 9.17 & 6.12 & 14.24 & 21.37 & 30.25 \\
\hline $\mathrm{SE}(\mathrm{m}) \pm$ & 0.74 & 0.24 & 0.39 & 0.44 & 0.91 & 0.02 & 0.02 & 0.08 & 0.10 & 0.06 & 0.12 & 0.16 & 0.18 \\
\hline CD at $5 \%$ & N.S. & N.S. & 1.22 & 1.38 & 2.84 & N.S. & 0.08 & 0.28 & 0.31 & N.S & 0.39 & 0.51 & 0.57 \\
\hline
\end{tabular}

Table 1. Influence of various treatments on different pre-harvest traits of mustard at different growth stages 


\begin{tabular}{|c|c|c|c|c|c|c|c|c|c|c|c|c|c|}
\hline Interactio & & & & & & & & & & & & & \\
\hline $\mathrm{SE}(\mathrm{m}) \pm$ & 1.66 & 0.54 & 0.86 & 0.98 & 2.17 & 0.02 & 0.03 & 0.14 & 0.18 & 0.13 & 0.27 & 0.30 & 0.41 \\
\hline CD at $5 \%$ & N.S. & N.S. & N.S. & N.S. & N.S. & N.S. & N.S. & N.S. & N.S. & N.S. & N.S. & N.S. & N.S. \\
\hline G.M. & 156 & 9.58 & 134.54 & 144.8 & 155.77 & 2.54 & 5.75 & 8.56 & 9.6 & 6.59 & 15.16 & 21.81 & 31.34 \\
\hline
\end{tabular}

The data presented in table-1 revealed that final plant stand at harvest of mustard as influenced by different sowing dates was statistically non-significant during the investigation. The data revealed that interaction effect due to sowing dates and varieties on emergence count at 15 DAS and final plant stand at harvest was found to be non-significant during the study.

Data collected in respect of mean periodical plant height of mustard as influenced by different treatments indicated that mean height of plant increases with successive stages of crop growth from 9.58 $\mathrm{cm}$ at 30 DAS to $155.77 \mathrm{~cm}$ at harvest stages. Mean height was increase in between 30 to 60 DAS. Thereafter it slowed down towards maturity. The data indicated that sowing dates showed at 30 DAS non significant variation on plant height while statistically significant at 60,90 DAS and at harvest. From all observations $\mathrm{D}_{2}$ (43 $\mathrm{rd}$ MW) recorded significantly more plant height at 60 and 90 DAS and at harvest than rest of sowing dates. At 60 and 90 DAS treatment $\mathrm{D}_{3}$ (44th $\left.\mathrm{MW}\right)$ at par with $\mathrm{D}_{4}$ (45 th $\left.\mathrm{MW}\right)$, at harvest $\mathrm{D}_{1}\left(42^{\text {nd }} \mathrm{MW}\right)$ at par with $\mathrm{D}_{3}$ (44th MW) while lowest plant height at $D_{5}\left(46^{\text {th }}\right.$ MW). The accumulated heat units and the number of days of maximum plant height decreased due to successive delay in sowing. Similarly results were reported by Singh et. al. (1993), Shivani and Sanjiv Kumar (2002) and Ghanbahadur and Lanjewar (2004). The data also revealed that plant height was non significant at 30 DAS while significant at 60, 90 DAS and at harvest. The plant height was significantly maximum in $\mathrm{V}_{1}$ (Pusa bold) over $\mathrm{V}_{2}$ (ACN-9). Reduction in plant height may be due to shorter life span of variety resulted forced maturity. Similar, results were reported by Sharma (2006) and Awasthi et. al., (2007). Interaction due to sowing dates with varieties was found to be non-significant at all the stage of crop growth.

The data revealed that, the number branches plant ${ }^{-1}$ were increased progressively with enhancement in crop duration. The number of branches plant ${ }^{-1}$ at 30 DAS was 2.54 and 9.6 at harvest. Effect of sowing dates does not show significance influence on number of branches plant ${ }^{-1}$ at 30 DAS while significant at 60, 90 DAS and at harvest. Sowing date $\mathrm{D}_{2}$ (43 ${ }^{\text {rd }}$ MW) recorded significantly higher number of branches plant ${ }^{-1}$ over $\mathrm{D}_{3}$ (44th $\left.\mathrm{MW}\right), \mathrm{D}_{4}$ (45 th $\mathrm{MW})$ and $\mathrm{D}_{5}\left(46^{\text {th }} \mathrm{MW}\right)$. Treatment $\mathrm{D}_{1}\left(42^{\text {nd }}\right.$ MW) at par with $\mathrm{D}_{3}$ (44th $\left.\mathrm{MW}\right)$ at 60, 90 DAS and treatment $D_{1}\left(42^{\text {nd }} \mathrm{MW}\right)$ at par with $\mathrm{D}_{3}$ (44th $\mathrm{MW}$ ) and $\mathrm{D}_{3}$ (44th $\mathrm{MW}$ ) at par with $\mathrm{D}_{4}$ (45 $\left.{ }^{\text {th }} \mathrm{MW}\right)$ at harvest, lowest number of branches recorded at treatment $D_{5}$ (46 th MW). However, it was observed that significant reduction in number of branches per plant with delay in sowing by each successive meteorological week due to high temperature. These findings are close accordance with Belgammwar (1998), Ghanbahadur and Lanjewar (2004). Varieties showed significant influence on number of branches plant ${ }^{-1}$ at all growth stages but non significant at 30 DAS. V 1 (Pusa bold) found significantly superior over $\mathrm{V}_{2}$ (ACN-9) at all periodic interval. Reduction in number of branches plant ${ }^{-1}$ due to genetic variation in variety. These results were in conformity with the finding of Ghanbahadur and Lanjewar (2004). Interaction effect between sowing dates with varieties was found to be non-significant at all stage of crop growth during the experimentation.

Accumulation dry matter plant ${ }^{-1}$ (g) is considered as the best index of crop growth put forth by crop. It would be observed that the rate of dry matter accumulation plant ${ }^{-1}$ was found progressively increased with physiological maturity of crop. The crop was slow in dry matter accumulation up to 30 DAS and produced only $6.59 \mathrm{~g}$ mean dry matter accumulation plant $^{-1}$ (g). The mean maximum accumulation of dry matter plant ${ }^{-}$ ${ }^{1}$ (g) was $31.34 \mathrm{~g}$ at harvest. Effect of sowing dates on dry matter accumulation plant ${ }^{-1}$ was non significant at 30 DAS while significant at 60, 90 DAS and at harvest, dry matter accumulation plant ${ }^{-1}$ was 
significantly maximum in $\mathrm{D}_{2}$ (43 ${ }^{\text {rd }} \mathrm{MW}$ ) over

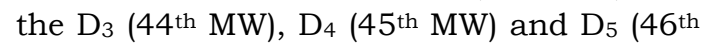
MW) while at par with $\mathrm{D}_{1}$ (42nd $\left.\mathrm{MW}\right)$ at 90 DAS, D 1 (42nd $M W)$ at par with $\mathrm{D}_{3}$ (44th $\mathrm{MW}$ ) at 60 DAS and at harvest while significantly lowest among treatments D5 (46 ${ }^{\text {th }}$ MW).Dry matter accumulation plant ${ }^{-1}$ (g) was decreased due to late sowing. Optimum sowing period facilitates luxurious crop growth resulting in maximum dry matter accumulation. These results are conformation with the finding reported by Rajendra Kumar et. al., (2002), Ghanbahadur and Lanjewar (2004) and Sharma (2006). Dry matter accumulation plant $^{-1}$ (g) due to influence of varieties was found non significant at 30 DAS while significant at 60, 90 DAS and at harvest.
However, with passage of time dry matter accumulation plant ${ }^{-1}$ found to be significantly increased. It was recorded $32.43 \mathrm{~g}$ significantly maximum at harvest in $\mathrm{V}_{1}$ (Pusa bold). $\mathrm{V}_{1}$ (Pusa bold) found to be superior over $\mathrm{V}_{2}(\mathrm{ACN}-9)$ over all treatments. Dry matter net assimilation rate was higher in $\mathrm{V}_{1}$ (Pusa bold) due to more number of days were required for 50 per cent flowering. These are in accordance with the findings reported by the Bhalerao (1997). Interaction effect between sowing dates with varieties was found to be non-significant at all stage of crop growth during the experimentation.

\section{Post -harvest studies}

Data regarding post harvest traits as influenced by various treatments are presented in Table-2.

Table 2. Influence of various treatments on different post-harvest traits, Thermal requirement and thermal use efficiency of mustard at different growth stages

\begin{tabular}{|c|c|c|c|c|c|c|c|c|c|c|c|c|c|c|c|}
\hline \multirow[t]{2}{*}{ Treatments } & \multirow{2}{*}{$\begin{array}{l}\text { Final } \\
\text { plant } \\
\text { stand } \\
\text { plot }^{-1}\end{array}$} & \multirow{2}{*}{$\begin{array}{l}\text { No. of } \\
\text { siliqua } \\
\text { e } \\
\text { plant }^{-1}\end{array}$} & \multirow{2}{*}{$\begin{array}{l}\text { Seed } \\
\text { yield } \\
\text { plant } \\
(\mathrm{g})\end{array}$} & \multirow{2}{*}{$\begin{array}{l}\text { Straw } \\
\text { yield } \\
\text { plant }{ }^{-1} \\
\text { (g) }\end{array}$} & \multirow{2}{*}{$\begin{array}{r}\text { Seed } \\
\text { yield } \\
(\mathrm{kg} \\
\left.\mathrm{ha}^{-1}\right)\end{array}$} & \multirow{2}{*}{\begin{tabular}{|c|}
$\begin{array}{c}\text { Straw } \\
\text { yield } \\
\text { (kg ha- } \\
\text { 1) }\end{array}$ \\
\end{tabular}} & \multirow{2}{*}{$\begin{array}{c}\text { Biomas } \\
\mathrm{s} \\
\left(\begin{array}{c}\mathrm{kg} \mathrm{ha} \\
1)\end{array}\right.\end{array}$} & \multirow{2}{*}{$\begin{array}{l}\text { Thermal } \\
\text { requirem } \\
\text { ent } \\
\left({ }^{\circ} \mathrm{C} \text { days }\right)\end{array}$} & \multicolumn{3}{|c|}{$\begin{array}{l}\text { Thermal use efficiency } \\
\left(\mathrm{kg} / \mathrm{ha} / \mathrm{D}^{\circ} \mathrm{C}\right)\end{array}$} & \multirow{2}{*}{$\begin{array}{c}\text { Total } \\
\text { cost of } \\
\text { cultivat } \\
\text { ion } \\
(\mathrm{Rs} \\
\left.\text { ha }^{-1}\right)\end{array}$} & \multirow{2}{*}{\begin{tabular}{|c|} 
Gross \\
moneta \\
ry \\
return \\
$(\mathrm{Rs}$ \\
$\left.\mathrm{ha}^{-1}\right)$
\end{tabular}} & \multirow{2}{*}{\begin{tabular}{|c} 
Net \\
moneta \\
ry \\
return \\
$(\mathrm{Rs}$ \\
$\left.\mathrm{ha}^{-1}\right)$
\end{tabular}} & \multirow[t]{2}{*}{$\begin{array}{l}\mathrm{B}: \mathrm{C} \\
\text { ratio }\end{array}$} \\
\hline & & & & & & & & & \begin{tabular}{|c|} 
Grain \\
yield \\
$(\mathrm{kg} /$ ha \\
$\left./ \mathrm{D}^{\circ} \mathrm{C}\right)$
\end{tabular} & \begin{tabular}{|c|}
$\begin{array}{c}\text { Straw } \\
\text { yield } \\
(\mathrm{kg} / \mathrm{ha} \\
\left./ \mathrm{D}^{\circ} \mathrm{C}\right)\end{array}$ \\
\end{tabular} & $\begin{array}{l}\text { Biomas } \\
\text { s yield } \\
\text { (kg/ha } \\
\left./ \mathrm{D}{ }^{\circ} \mathrm{C}\right)\end{array}$ & & & & \\
\hline \multicolumn{16}{|l|}{ Sowing Dates } \\
\hline $\begin{array}{l}D_{1}-42^{\text {nd }} \\
\text { MW }\end{array}$ & 156 & 134.87 & 6.33 & \begin{tabular}{|l|}
19.43 \\
\end{tabular} & 771 & 1949.8 & 2720.8 & 1763.19 & 0.44 & 1.11 & 1.54 & 15625 & 28275 & 12650 & 1.81 \\
\hline $\mathrm{D}_{2}-43^{\mathrm{rd}} \mathrm{MW}$ & 159 & 141.98 & 7.27 & 21.05 & 820 & 2126.6 & 2946.6 & 1818.88 & 0.45 & 1.17 & 1.62 & 15625 & 30083 & 14458 & 1.93 \\
\hline $\mathrm{D}_{3}-44^{\text {th }} \mathrm{MW}$ & 157 & 125.83 & 6.12 & 16.58 & 727 & 1729.9 & 2456.9 & 1672.22 & 0.43 & 1.03 & 1.47 & 15625 & 26669 & 11044 & 1.71 \\
\hline $\mathrm{D}_{4}-45^{\text {th }} \mathrm{MW}$ & 155 & 116.17 & 5.57 & \begin{tabular}{|l|}
14.49 \\
\end{tabular} & 648 & \begin{tabular}{ll|}
1488.7 \\
\end{tabular} & 2136.7 & 1602.39 & 0.40 & 0.93 & 1.33 & 15625 & 23755 & 8130 & 1.52 \\
\hline $\mathrm{D}_{5}-46^{\text {th }} \mathrm{MW}$ & 154 & 109.56 & 5.08 & 12.59 & 579 & 1255.3 & 1834.3 & 1553.37 & 0.37 & 0.81 & 1.18 & 15625 & 21239 & 5614 & 1.36 \\
\hline \begin{tabular}{|l|}
$\mathrm{SE}(\mathrm{m}) \pm$ \\
\end{tabular} & 1.07 & 2.28 & 0.14 & 0.32 & 14.21 & \begin{tabular}{|l|}
50.63 \\
\end{tabular} & 109.8 & & & & & - & 879 & 879 & - \\
\hline CD at $5 \%$ & N.S. & 7.10 & 0.46 & 1.03 & 46.33 & 165.08 & 334.4 & & & & & - & 2865 & 2865 & - \\
\hline \multicolumn{16}{|l|}{ Varieties } \\
\hline $\begin{array}{l}\mathrm{V}_{1}-\text { Pusa } \\
\text { bold }\end{array}$ & 157 & 129.92 & 6.69 & \begin{tabular}{|l|}
17.54 \\
\end{tabular} & 733 & 1827.6 & 2560.6 & 1632.0 & 0.45 & 1.12 & 1.56 & 15625 & 26864 & 11239 & 1.72 \\
\hline $\mathrm{V}_{2}-\mathrm{ACN}-9$ & 156 & 121.44 & 5.46 & 16.12 & 686 & 1645.7 & 2331.7 & 1535.51 & 0.44 & 1.07 & 1.51 & 15625 & 25144 & 9519 & 1.61 \\
\hline $\mathrm{SE}(\mathrm{m}) \pm$ & 0.74 & 1.11 & 0.32 & 0.44 & 14.89 & 52.06 & 113.05 & & & & & - & 945 & 945 & - \\
\hline CD at $5 \%$ & N.S. & 3.50 & 1.02 & 1.39 & 46.91 & 164.02 & 339.15 & & & & & - & 2980 & 2980 & - \\
\hline \multicolumn{16}{|l|}{ Interaction } \\
\hline D1V1 & & & & & 789 & & & & & & & & & & \\
\hline D1V2 & & & & & 753 & & & & & & & & & & \\
\hline D2V1 & & & & & 853 & & & & & & & & & & \\
\hline D2V2 & & & & & 788 & & & & & & & & & & \\
\hline D3V1 & & & & & 750 & & & & & & & & & & \\
\hline D3V2 & & & & & 705 & & & & & & & & & & \\
\hline D4V1 & & & & & 671 & & & & & & & & & & \\
\hline D4V2 & & & & & 624 & & & & & & & & & & \\
\hline D5V1 & & & & & 600 & & & & & & & & & & \\
\hline D5V2 & & & & & 558 & & & & & & & & & & \\
\hline $\mathrm{SE}(\mathrm{m}) \pm$ & 1.66 & 2.49 & 0.73 & 0.98 & 33.30 & 116.41 & 145.3 & & & & & - & & & - \\
\hline CD at $5 \%$ & N.S. & N.S. & N.S. & N.S. & 104.90 & 336.77 & 460.7 & & & & & - & N.S. & N.S. & - \\
\hline G.M. & 156 & 125.68 & 6.07 & 16.83 & 709 & $\begin{array}{c}1717.6 \\
6\end{array}$ & $\begin{array}{c}2426.7 \\
8\end{array}$ & 1653.94 & 0.42 & 1.03 & 1.46 & 15625 & 26004 & 10379 & 1.66 \\
\hline
\end{tabular}

From the data it would be noticed that various treatments showed significant influence on the number of siliquae plant ${ }^{-1}$. Mean number of siliquae plant $^{-1}$ was
125.68. Data indicated that, sowing time showed significance influence on number of siliquae plant ${ }^{-1} . \mathrm{D}_{2}$ (43 $\left.{ }^{\text {rd }} \mathrm{MW}\right)$ produce more number of siliquae plant-1 over $D_{1}\left(42^{\text {nd }}\right.$ 
MW), $\mathrm{D}_{3}$ (44th $\left.\mathrm{MW}\right), \mathrm{D}_{4}$ (45 $\left.{ }^{\text {th }} \mathrm{MW}\right)$ and $\mathrm{D}_{5}$ (46 ${ }^{\text {th }}$ MW) while treatment $\mathrm{D}_{4}\left(4^{\text {th }} \mathrm{MW}\right)$ found to be at par with $\mathrm{D}_{5}$ (46 th $\mathrm{MW}$ ). Siliquae initiation was progressively delayed due to late sowing as the crop took more days to flower initiation in late or advanced sowing after branching. These findings were close accordance with the Balgamwar (1998), Shashtry and Arvind kumar (1981). Among the two varieties $\mathrm{V}_{1}$ (Pusa bold) found to be significantly superior over $V_{2}$ (ACN-9). It seems due to variation in respect of number of siliquae plant ${ }^{-1}$ among different mustard varieties. Interaction effect between sowing dates with varieties was found to be non-significant at all stage of crop growth during the experimentation.

The data in respect of seed yield plant ${ }^{-1}$ as influenced by different treatments revealed that seed yield plant ${ }^{-1}$ (g) was influenced significantly due to various treatments. On an average, the mean seed yield plant-1 (g) of $6.07 \mathrm{~g}$ was recorded. Among sowing dates, sowing on $\mathrm{D}_{2}\left(43^{\mathrm{rd}}\right.$ MW) recorded significantly higher seed yield plant $^{-1}(7.27 \mathrm{~g})$ than $\mathrm{D}_{1}$ (42nd $\left.\mathrm{MW}\right), \mathrm{D}_{3}$ (44th MW), D4 (45 th $M W)$ and D5 (46 th $M W)$ while treatment $D_{1}\left(42^{\text {nd }} \mathrm{MW}\right)$ found to be at par with $\mathrm{D}_{3}$ (44th $\mathrm{MW}$ ). Delay in sowing might be reducing the seed yield plant $^{-1}$ (g) due to environmental conditions. The results are in close accordance with the findings of Ghanbahadur and Lanjewar (2004). Different varieties had significant influence on the seed yield plant ${ }^{-1}$. The variety $V_{1}$ (Pusa bold) recorded higher seed yield plant 1 (6.69 g) than $\mathrm{V}_{2}$ (ACN-9). This result is due to the variety to variety variation between their potential to produce seed yield plant ${ }^{-1}$ (g). The results are in conformation with the findings reported by Bhalerao (1997). Interaction effect between sowing dates and varieties found to be non-significant.

The data in respect of straw yield plant ${ }^{-1}$ as influenced by different treatments revealed that straw yield plant ${ }^{-1}$ (g) was influenced significantly due to vary treatments. On an average, the mean straw yield plant $^{-1}(\mathrm{~g})$ found $16.83 \mathrm{~g}$ was recorded. Among the sowing dates, on $\mathrm{D}_{2}$ (43 ${ }^{\text {rd }} \mathrm{MW}$ ) recorded significantly higher straw yield plant $^{-1}(21.05)$ than $\mathrm{D}_{3}$ (44th $\left.\mathrm{MW}\right), \mathrm{D}_{4}$ (45 th MW) and $D_{5}$ (46.th $\left.M W\right)$ but found to be at par with $\mathrm{D}_{1}\left(42^{\text {nd }} \mathrm{MW}\right)$. Delay in sowing was significantly reduced the straw yield plant ${ }^{-1}$ (g) due to environmental conditions. Difference in varieties significantly influence over straw yield plant ${ }^{-1}$. The variety $\mathrm{V}_{1}$ (Pusa bold) found to be at par with $\mathrm{V}_{2}$ (ACN-9) producing straw yield plant ${ }^{-1}(\mathrm{~g})$ which was $(17.54 \mathrm{~g})$ as compared with $\mathrm{V}_{2}$ (ACN-9). The interaction effect between sowing dates and varieties were found to be non-significant.

The mean seed yield was observed to be 709 (kg ha-1). Seed yield showed significant influence on date of sowing. Sowing date $\mathrm{D}_{2}$ (43 $\left.{ }^{\text {rd }} \mathrm{MW}\right)$ recorded highest value of seed yield (820 kg ha-1) over $\mathrm{D}_{1}\left(42^{\mathrm{nd}} \mathrm{MW}\right), \mathrm{D}_{3}$

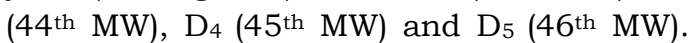
$\mathrm{D}_{1}$ (41 st $\mathrm{MW}$ ) found to be at par with $\mathrm{D}_{3}$ (44th MW). Sowing in $42^{\text {nd }}$ MW resulted in early flowering, longer seed filling period, a longer reproductive phase and ultimately a higher seed yield per unit area. Increased yield contributing characters reflected in higher seed yield. These results are in conformation with the findings of Shashtry and Arvind Kumar (1981), Tyagi et.al, (1996), Zora Singh et.al, (1998) and Ghanbahadur and Lanjewar (2004) who also reported significant influence of sowing date on seed yield in mustard. Seed yield showed significant influence on variety. Variety $\mathrm{V}_{1}$ (Pusa bold) recorded highest value of seed yield (733 $\left.\mathrm{kg} \mathrm{ha}^{-1}\right)$ than $\mathrm{V}_{2}$ (ACN-9). Higher seed yield from $\mathrm{V}_{1}$ (Pusa bold) due to longer seed filling period and longer reproductive phase resulted in higher yield. These findings are closed accordance with Shashtry and Arvind Kumar (1981) and Gupta and Saini (2004). Significant influence on sowing dates and varieties observed on seed yield ( $\left.\mathrm{kg} \mathrm{ha}^{-1}\right) . \mathrm{D}_{2}$ (43 rd MW) sowing with combination with $\mathrm{V}_{1}$ (Pusa bold) in every row proved significantly superior over rest of the treatment combination.

The data regarding mean straw yield $\mathrm{kg}$ ha $^{-1}$ exhibited that various treatments showed significant influence over straw yield $\mathrm{kg} \mathrm{ha}^{-1}$. The mean straw yield was 1717.66 $\mathrm{kg} \mathrm{ha}{ }^{-1}$. Among the five dates of sowing, the mean straw yield $\mathrm{kg} \mathrm{ha}^{-1}$ was observed to be highest while mustard sown on $\mathrm{D}_{2}\left(43^{\text {rd }}\right.$ MW) recorded significantly higher straw yield ha-1 $(2126.6 \mathrm{~kg})$ as compared with the 
mustard sown on $\mathrm{D}_{3}$ (44th $\left.\mathrm{MW}\right), \mathrm{D}_{4}$ (45 th MW) and D5 (46th MW) while found to be at par with $\mathrm{D}_{1}$ (42 $\left.{ }^{\text {nd }} \mathrm{MW}\right)$. Among two different varieties i.e. $\mathrm{V}_{1}$ (Pusa bold) and $\mathrm{V}_{2}$ (ACN-9), variety $\mathrm{V}_{1}$ (Pusa bold) found to be significantly superior over $\mathrm{V}_{2}$ (ACN-9), with straw yield $1827.6 \mathrm{~kg} \mathrm{ha}^{-1}$.The interaction effect of sowing dates and varieties on mean straw yield ha ${ }^{-1}$ were found to be significant. The straw yield ha-1 for mustard sown on $\mathrm{D}_{2}$ (43 ${ }^{\text {rd }}$ MW) recorded higher straw yield ha-1 $(2126.6 \mathrm{~kg})$ over rest of the treatment combinations. This might be due to the cumulative effect of all the growth characters which was higher in this interaction.

The data revealed that the biomass ha-1 $^{-1}$ was significantly influenced due to variation among the sowing dates of mustard varieties. On an average, the mean biomass of $2426.78 \mathrm{~kg} \mathrm{ha}^{-1}$ was recorded. Among the five dates of sowing, the mean biomass $\mathrm{kg} \mathrm{ha}^{-1}$ was observed to be highest while mustard sown on $\mathrm{D}_{2}$ (43 rd $\mathrm{MW}$ ) recorded significantly higher biomass (2946.6 $\mathrm{kg} \mathrm{ha-1)}$ as compared with the mustard sown on $\mathrm{D}_{3}$ (44th $\left.\mathrm{MW}\right), \mathrm{D}_{4}$ (45 th MW) and $D_{5}$ (46.th $\mathrm{MW}$ ) found to be at par with $\mathrm{D}_{1}\left(42^{\text {nd }} \mathrm{MW}\right)$ while $\mathrm{D}_{1}$ (42 ${ }^{\text {nd }} \mathrm{MW}$ ) found to be at par with $\mathrm{D}_{3}$ (44th $\mathrm{MW}$ ). Among two different varieties $V_{1}$ (Pusa bold) and $V_{2}$ (ACN-9), variety $\mathrm{V}_{1}$ (Pusa bold) found to be significantly superior over $\mathrm{V}_{2}$ (ACN-9), with $2560.6 \mathrm{~kg} \mathrm{ha}^{-1}$ biomass. The interaction effect of sowing dates and varieties on mean biomass $\mathrm{kg} \mathrm{ha}^{-1}$ were found to be significant. The biomass ha-1 for mustard sown on $\mathrm{D}_{2}\left(43^{\text {rd }} \mathrm{MW}\right)$ recorded higher biomass $\left(2946.6 \mathrm{~kg} \mathrm{ha}^{-1}\right)$ over rest of the treatment combinations. This might be due to the cumulative effect of all the growth characters which was higher in this interaction.

\section{Weather parameter}

Data collected on thermal requirement for the mustard are presented in Table- 2 The thermal requirement is reduced as the sowing is delayed. Sowing in $43^{\text {rd }} \mathrm{MW}$ recorded highest thermal requirement and sowing in $46^{\text {th }}$ MW recorded the lowest thermal requirement. Similar results are reported by Singh et al. (2014). The different varieties recorded different thermal requirement variety Pusa bold recorded highest thermal requirement followed by variety ACN-9 Similar result are reported by Singh et al. (2014).

Data collected on thermal use efficiency on the basis of grain yield, straw yield and biomass yield for various varieties of mustard are presented in Table-2. Data revealed that different sowing dates showing thermal use efficiency in case of grain yield in mustard crop. Sowing on 43 ${ }^{\text {rd }}$ MW recorded higher thermal use efficiency $\left(0.45 \mathrm{~kg} / \mathrm{ha} / \mathrm{D}^{\circ} \mathrm{C}\right)$ and it was significantly superior over other sowing. The lowest thermal use efficiency was recorded with sowing in 46th MW. Same trend were observed in straw yield and in biomass yield where plant with sowing taken on 43rd MW shown significantly higher thermal use efficiency i.e. (1.17 and $\left.1.62 \mathrm{~kg} / \mathrm{ha} / \mathrm{D}^{0} \mathrm{C}\right)$, respectively. Thermal use efficiency reduced with late sowing date on 46 $\mathrm{\text {th }}$ MW for both straw yield and biomass yield. Similar results reported Akhter et. al., (2016). Data also revealed that variation among different varieties in respect of grain yield, straw yield and biomass yield. In grain yield, variety Pusa bold has shown significant highest thermal use efficiency $\left(0.45 \mathrm{~kg} / \mathrm{ha} / \mathrm{D}{ }^{\circ} \mathrm{C}\right)$ which is followed by variety ACN-9, in straw yield variety Pusa bold has significant highest thermal use efficiency (1.12 $\mathrm{kg} / \mathrm{ha} / \mathrm{D}^{\circ} \mathrm{C}$ ) followed by variety $\mathrm{ACN}-9$. The highest thermal use efficiency is shown by variety Pusa bold with biomass yield (1.56 $\mathrm{kg} / \mathrm{ha} / \mathrm{D}^{\circ} \mathrm{C}$ ) which is followed by variety ACN-9. Similar result reported by Akhter et. al., (2016).

\section{Economic study}

Data regarding gross monetary returns, net monetary returns and $\mathrm{B}$ : $\mathrm{C}$ ratio is presented in Table-2. The mean gross and net monetary returns were Rs. 26004 ha-1 $^{-1}$ and Rs. 10379, respectively. Highest gross and net monetary returns of Rs. 30083 and Rs. 14458 ha $^{-1}$ respectively, were recorded when crop sown on 43rd MW which was significantly superior over other sowing dates. Increase in net and gross monetary return is due to significant increase in the economic yield of mustard. Highest gross monetary returns of Rs. 26864 ha $^{-1}$ and net monetary returns of Rs. 11239 ha $^{-1}$ were 
recorded with variety Pusa bold which was significantly superior over variety ACN-9. Interaction of sowing dates and varieties was found to be non-significant. Mean B: C ratio of mustard crop obtained was 1.66. Highest B: C ratio of 1.93 was recorded with sowing on $43^{\text {rd }} \mathrm{MW}$ as compared to other sowing dates. Increase in $\mathrm{B}$ : $\mathrm{C}$ ratio is due to significant increase in gross monetary return. Comparatively higher $\mathrm{B}$ : $\mathrm{C}$ ratio 1.72 is recorded with variety Pusa bold over ACN-9.

On the basis of result obtained during the course of present experimentation, it is concluded that Sowing of mustard during 43 rd MW significantly improved all the growth and yield components as compared to sowing of mustard during $42^{\text {nd }}, 44^{\text {th }}, 4^{\text {th }}$ and $46^{\text {th }}$ MW resulting in significant increase in seed yield of mustard. Among the two different cultivars of mustard, Pusa bold recorded significantly higher growth rate, seed yield and yield components, resulting as compare to ACN-9. Thermal requirement and thermal use efficiency of mustard was more when crop sown on $43^{\text {rd }}$ $\mathrm{MW}\left(\mathrm{D}_{2}\right)$.

References:

Akhter S., L. Singh., A. Saxena, R. Rasool, R. Jan and I. Showqi, 2016. Agro meteorological indices for brown sarson sown under different dates of sowing in temperate region of Kashmir. National Environment Association 11(1): 279-283.

Anonymous, (1999) pre-released proposal for mustard ACN-9, submitted to research review committee, Dr. P.D.K.V. Akola, 1-2. Annoymous. 2014a. Agricultural Statistics at glance.

Annoymous. 2014b. Joint Directorate of Agriculture Nagpur division.

Awasthi, U.D., R.B. Singh and S.D. Dubey, 2007. Effect of sowing dates and moisture conservation practice on growth and yield of Indian mustard (Brassica juncea) varieties. Indian J. of Agronomy 52(2): 151-153.

Belgamwar, M.M, 1998. Crop weather relations as influenced by dates of sowing in mustard (Brassica juncea) M.Sc. Thesis Dr. P.D.K.V. Akola (M.S.).

Bhalerao, P.D. (1997) Response of mustard (Brassica juncea) varieties to nitrogen levels of under varied moisture regime. Ph.D. Thesis Dr. P.D.K.V. Akola (M.S.).

Ghanbahadur, M. R. and B.K. Lanjewar, 2004. Performance of Indian mustard
(Brassica juncea) varieties with respect to sowing dates, irrigation levels and mulching. PKV. Res. J. 28(2): 186-187.

Gupta, T.S., and J.S. Saini (2004) Effect of sowing date and application of nitrogen on seed and oil yield of toria. Indian $\mathrm{J}$. of Agronomy 27(4): 326-329.

Panse, V. G. and P. V. Sukhatme (1971) Statistical method for Agriculture workers, IARI, New Delhi

Rajendra Kumar, (2002) Effect of nitrogen on sowing dates on productivity of Brassica spp., Indian J. of Agronomy 47(3): 411-417.

Sharma S. K, 2006. Effect of sowing and irrigation management on growth and yield of mustard (Brassica juncea) M.Sc. Thesis, Dr. P.D.K.V. Akola, College of Agriculture, Nagpur.

Shashtry, A.B. and Arvind Kumar,1981. Variation in yield and quality of Indian mustard in relation to planting time and levels of plant population. Indian J. of Agric. Sci. 51(1): 27-32.

Shivani Kumar and Sanjeev Kumar, 2002. Response of Indian mustard (Brassica juncea) to sowing dates and row spacing in mid-hills of Sikkim under rainfed conditions. Indian J. of Agronomy 47(3): 405-410.

Singh A. K., R. P. Singh., A. Kumar., and P. K. Singh, 2014. Influence of dates of sowing and irrigation scheduling on growth and yield of mustard (Brassica juncea). International J. Farm Sciences 4(2): 80-85.

Tyagi, P.K., Singh, V.U.M. Rao and A. Kumar, 1996. Effect of sowing dates on phonological development of mustard (Brassica juncea) varieties. Crop Res. Hissar 11(2): 151-155.

Zora Singh, Brar, Daljit Singh Bal and Anupam Singh Johl, 1998. Influence of sowing dates, nitrogen and planting geometry on the performance of gobhi sarson (Brassica napus spp. Oleifere var. annua). Indian J. of Agronomy 43(1): 133137. 